\title{
The On-Going Price of Perceiving Money as a Veil
}

\author{
Emir Phillips ${ }^{1}$ \\ ${ }^{1} \mathrm{JD} / \mathrm{MBA}$ MSFS, ChFC CLU is a candidate in the DBA Program at the Grenoble École de Management, \\ Grenoble, France \\ Correspondence: Emir Phillips, JD/MBA MSFS, ChFC CLU is a candidate in the DBA Program at the Grenoble \\ École de Management, 1937 22nd St \#1, Santa Monica, CA 90404, Grenoble, France. Tel: 310-930-6360. E-mail: \\ emirphil@yahoo.com
}

Received: September 20, 2017

Accepted: November 15, 2017

Online Published: November 20, 2017

doi:10.5539/ijef.v9n12p215

URL: https://doi.org/10.5539/ijef.v9n12p215

\begin{abstract}
Until macroeconomic theory rebuffs the nature of finance, which is leverage (debt claims and credit instruments above current GDP output), shadow-banking will continue to lure capital into the financial sector, lower institutional banking interest rates, and de-incentivize commercial lending from the real sector, even at competitive risk-adjusted rates. This institutionalized misallocation of credit undermines the tidy neoclassical "circular flow" apparatus where savings and earnings are allegedly pooled and then recycled through financial intermediaries into dynamic investment.

Despite the mathematical complexity of DSGE models, the last financial crisis and its aftermath exposed the models' inadequacy for forecasting or even fully capturing economic reality. With no dynamic function for money, incorporating credit into the theoretical mindset of mainstream economics, including both neoliberal and (Post)-Keynesian traditions, has proven as yet unattainable. Holding fast to a (barter-like) Walrasian worldview, wherein the neutrality of money in the long-run, has meant debt does not exist and credit aggregates are not considered due to an a-historical mis-conceptualization of money/credit. As long as money, credit and debt are not accorded special roles, a bloated financial sector may well contribute to the suboptimal allocation of talents. This Article shows how by design, DSGE models do not recognize either credit's beneficent growth properties, or credit's aptitude to precipitate crisis by augmenting, largely non-GDP financial income, while in the long-run simultaneously reducing earned income (GDP recognized).
\end{abstract}

Keywords: theory of money, DSGE models, open economy macroeconomics, flow of funds, international banking

\section{Economic Theory Views Money as Emanating From Barter, and Is Neutral in the Economy: A Mere Veil over the Real Economy of Goods and Services}

The paradigm of mainstream macroeconomics for nearly two hundred years has held firmly that a barter economy would exist without money and finance.

"There cannot, in short, be intrinsically a more insignificant thing, in the economy of society, than money." John Stuart Mill, Principles of Political Economy with Some of Their Applications to Social Philosophy (1848).

Thus, using of money as a medium of exchange obscures the economic phenomena beneath "the veil of money." The metaphor of money as a veil was a core concept of classical economics and is still foundational in the macroeconomic models used to forecast national economies. But there is a sinister cost in institutionally perceiving money as nothing more than a hijab. Yet, since this neoliberal paradigm emanates from industrial capitalism, it should come as no surprise that production jump-starts this paradigmatic model. Manufacturers use employment and production to turn out goods and services, which creates various income streams (take-home pay, interest revenue, rental revenue, etc.) from manufacturers' cost of production. As recipients of these incomes pay for the produced goods, they inevitably institute symmetry between income (supply) and expenditures (demand). Yet this income-expenditure poise is tautological; outlay of production to employers is simultaneous income for factors of production. This feedback loop is often illustrated by a diagram labeled the "circular flow."

The circular flow model permits transitory discrepancies involving income and expenditures. For instance, when the wealthy save a fraction of their high incomes, the inevitable balance soon reasserts itself when through banks and other financial intermediaries, these savings are borrowed and then invested by manufacturers who seal the 
discrepancy between aggregate spending and income. Steadiness between supply and demand prevails if the aggregate national savings equals aggregate national investment expenditures.

Insufficient investment spending relative to aggregate savings persists indefinitely-even in the liberal/Keynesian account of neoclassical economics where automatic restoration of equilibrium is not guaranteed. Under this relative market uncertainty, even low interest rates may not persuade manufacturers to take on loans and develop the real sector. Also, under this condition of extremely low interest rates, holders of "idle" savings may prefer to stay liquid until rates increase again (Note 1).Under such circumstances, the government should intervene by borrowing the "idle" savings and spending the bond funds to close the savingsinvestment (or income-expenditures) discrepancy (Note 2).

Accordingly, the supply of money and credit corresponds to the amount of national savings bounded by aggregate supply/output, or national income (GDP). Although central bank "fractional reserve banking" can expand credit beyond the quantity of savings, the amount of loan money by banks is constrained by national savings. This ongoing neoclassical paradigm, of both neoliberal and Keynesian traditions is a consequence of their reliance on Leon Walras' barter-exchange, general-equilibrium model wherein, theoretically speaking, money is not capable of de-coupling from the real sector since it is only a neutral veil.

Perhaps, at one time, savings were the primary source of financing for real investment projects when commercial banks acted as financial intermediaries between investors and savers by recycling savings into credit/money for fruitful venture. Today however, commercial banks are not only self-determining but also dominate the real sector of the economy. Specifically, commercial banks create credit irrespective of the "real" economy.

The neoliberal model of money/credit multiplier is obsolete and founded on the miscomprehension that deposits are deposited. These days, fiat money is almost exclusively electronic and can be created instantly at the discretion of individual commercial banks or the central bank.

\section{Modern Commercial Banks Do Not Increase the Money Supply through Fractional Reserve Banking}

While it is true that the banking system lends amounts many multiples greater than the cash and reserves in custody at the Federal Reserve, it is not because banks are mere 'financial intermediaries' passing on deposited money as loans or because the central bank has considerable control over the reserve amounts held by banks (Note 3). Commercial banks do not react passively to customers' deposits, which must precede lending. Bank credit/money creation does not funnel existing money to novel employ, but instead creates new credit/money that did not exist beforehand and then funnels it to some use.

Piti Distayat (2011) of the Bank for International Settlements stated, the emphasis on policy-induced changes in deposits is misplaced. If anything, the process actually works in reverse, with loans driving deposits. In particular, it is argued that the concept of the money multiplier is flawed and uninformative in terms of analyzing the dynamics of bank lending. Under a fiat money standard and liberalized financial system, there is no exogenous constraint on the supply of credit except through regulatory capital requirements. An adequately capitalized banking system can always fulfill the demand for loans if it wishes to.

Today the vast majority of money is created by banks upon issuance of loans (Werner, 2014). Banks simply do not wait for deposited money to create a loan. This is why the monetary base (reserves and cash) does not increase before the banks make loans, as fractional reserve banking would suggest. Rather, this occurs later:

There is no evidence that either the monetary base or M1 leads the [credit] cycle, although some economists still believe this monetary myth. Both the monetary base and $\mathrm{Ml}$ series are generally pro-cyclical and, if anything, the monetary base lags the [credit] cycle slightly (Kydland \& Prescott, 1990).

The mechanism for credit extension to increased economic transactions consists of loans causing deposits and those deposits cause a spurt of transactions (Caporale \& Howells, 2001). Money/credit is no longer a lubricant or veil to the real economy; rather, it is a vital mechanism for economic growth or monetary disorder.

\section{Commercial Banks Are not Intermediaries of Money: They Create Money}

Every increase through bank credit creation impacts the value of economic transactions. In contrast to central bank policy theories, this bank-money creation plays a crucial role in stimulating nominal demand growth. Banks do not lend money; they create it. Each individual bank creates credit and money when it extends financing, which then circulates (Werner, 2016).

Clearly then, banks do not intermediate already existing money. Instead, in reverse, the credit asset on the commercial bank's balance sheet is matched by a money liability when a loan is extended (Friedman, 2012). By extending loans, banks create credit, money, and thus purchasing power through "maturity transformation." 
While the loan is repayable later, the borrowed money is available immediately. All money not in cash operates in this fashion. That is, commercial banks extend credit by creating money. When creditworthy borrowers can be found, banks are highly pro-active in creating credit/money. Central banks react and inevitably oblige commercial banks' demand for reserves. Commercial banks initially create credit/money, and subsequently scour for fractional re-financing. Thus, commercial banks and not central banks, chiefly determine the entire supply of money.

\section{When Acting Individually, Commercial Banks Tend to Exacerbate Asset Inflation While Disregarding the Real Economy}

Money is allegedly a neutral "veil" over the workings of the "real" economy--thus any dissimilarity in its quantity affects only the level of prices not production and growth in the real economy (GDP). This retains monetarism's underlying assumption by attributing any anomalies between quantities of money and prices both to the short-run and logically ad hoc factors such that money aggregates should be considered irrelevant. Money Quantity theory's adage of long-run monetary neutrality in the symmetry between real economic variables and nominal money misconstrues the very nature of money (Note 4).Money is volatile, and its production is partly self-referential, partly- societal and altogether allocative.

In an economic boom, bank perception of the future economy glistens. Rising asset/collateral values further encourage management at each individual bank to lower its estimates of risk, and hence the level of capital required. When using its ability to create money to maximize the amount of sound interest-bearing loans issued, and therefore maximize interest income, each commercial bank is subservient to the short-term interests of its shareholders. As long as banks systemically lend to one another, the banking system as a whole generates sufficient profits, capital and additional liquidity to keep the bubble afloat via more loans. But when the herd stops lending, the few still lending will be devoured by loans soon-to-be defaulted. This self-defeating cycle partly emanates from the design of capital adequacy rules that fundamentally neglect the ontological fact that commercial banks create the money supply. Greater capital adequacy requirements will not stymie a boom when banks can tap sufficiently increased bank credit to fund higher capital ratios.

Therefore, commercial bank "money" creation is not substantially confined by regulation, reserve ratios, the government or the Federal Reserve (Note 5), but only by bank confidence in the economy. In today's recessionary times, banks perceive world debt at an all-time high, and are keen to loan on collateralized assets and less eager to fund loans that might default and reduce their liquidity and capital adequacy. This credit/money creation process by commercial banks drives asset inflation that is not generally tied to the real economy.

\section{In the Real World, Credit/Leverage Now Far Exceeds the Real Economy}

The quondam credit system of advanced economies was restricted by national savings and then by the central bank's direction of the credit/money supply, but this is not true anymore and less so every day. The monetary system's institutional makeup gives commercial banks authority to create credit/money many multiples above their reserves, potentially enabling the credit/money supply of money to be more elastic than real economic sector output.

Most credit today is spent to purchase already-created assets, rather than to generate fresh real-sector productive capacity. Credit that finances trading in existing assets, real or financial, does not contribute to GDP, but fuels unsustainable asset inflation (Note 6).For example, in the Financial Crises, mortgage lending created new money and allocated it into the property market, which increased the demand for houses. House prices increased with the insufficient change in the quantity of houses available to purchase. "What determines house prices... is the number of people who have taken out a mortgage, and the dollar value of those mortgages ... For changes in house prices, what matters is the acceleration of mortgage debt" (Keen, 2013). By this acceleration, the financial sector not only further disengaged from the real sector (housing construction) but due to the limited availability of land and the general illiquidity of real estate it became the primary determinant of increasing the sale price (most of which is non-GDP). This, simultaneously increased residential values regardless of fundamentals while further crowding out credit from businesses, especially small-medium enterprises (SMEs).

To an alarming degree, corporate profits have not been reinvested for real-sector capacity enhancement. The bait of speculative earnings, aided by the far-reaching deregulation of the banking sector, entices money-capital to discard manufacturing in search of "safer" income from the financial sector (largely non-GDP). Before the 1980s, both real investment and corporate profitability accounted for approximately 9\% GDP. Subsequently, and particularly in recent memory, real project outlay has fallen to approximately $4 \%$ GDP, whereas corporate earnings have risen to approximately 12\% GDP (Harding, 2013). 
High corporate profits imply sizable opportunities to earn. Interest rates at historic lows, coupled with stock market highs, suggest that capital is decidedly economical. In contrast to economic theory, real investment has not ensued. In the neoclassical "general equilibrium" and/or "circular flow" paradigm, financial cycles crisply track real cycles and deepen when real cycles increase. Or when the financial cycle constricts then the real sector constricts. Within current paradigm, money implicitly facilitates exchange/barter/circulation, and not as an idyllic or final depository of concentrated or accumulated wealth. With bartering (economic transactions) trumping capital accumulation, scarcely any leeway exists for financial bubbles to materialize and swell free of the economy's real sector. The monetary system is essentially a handmaiden to the real sector.

Whether a financial bubble tracks real economic growth or whether the bubble emerges in the absence of such expansion is significant to learning how finance capital has disengaged from, and become principally autonomous of industrial capital. This disengagement has discredited the neoclassical notion of general equilibrium, the circular flow model as well as viewing domestic savings as the foremost font of credit/money. To summarize, how this financial sector disengagement from the real economy has rendered the hegemonic paradigm of venture financing, credit creation, and money supply is not merely outmoded, but institutionally hazardous when inculcated at the base of "Dynamic Stochastic General Equilibrium" (Note 7) (DSGE) models.

Due to neoclassical philosophical assumptions, credit cannot exist, and a credit crisis can neither be anticipated nor can the societal dynamic within the production of money(ness) be truly investigated, fathomed, or de-mystified. When DGSE models mathematically do not compute the self-referential credit dynamic of the recent Financial Crisis due to the philosophical assumptions from the neoclassicism of the 1870s, the nature of money/credit must be perceived anew.

\section{What Are the Consequences of not Modeling for Debt, Money, or Credit Regarding Destabilizing the Monetary System?}

One reason why outsized financial systems seem harmful to economic growth involves the prospective misallocation of resources, even in good times (Tobin, 1984). Finance is a skilled-labor-intensive industry (Philippon \& Reshef, 2009; Philippon, 2010). In the US, commercial banking has become relatively skilled-labor-intensive. The financial industry competes for resources with the real economy, necessitating not only material capital, but also highly accomplished workers. Skill-intensive niches also tend to be R\&D intensive and unduly debilitated when the financial sector expands too rapidly (Cahuc \& Challe, 2012). For example, manufacturing that is either $\mathrm{R} \& \mathrm{D}$ intensive or reliant on external finance would endure lopsided reductions in economic growth when finance booms (Cecchetti \& Kharroubi, 2012). Credit booms impair what is usually considered an engine for growth: an R\&D-intensive segment of the economy (Note 8).

Beyond a misallocation of skilled labor, credit itself may also be misdirected. Finance necessitates financing. Financial intermediaries vie with non-financial intermediaries for monetary capital. One can then surmise that firms that rely on external finance will compete more directly with financial intermediaries. By competing with the remainder of the economy for scant resources, expansive financial sectors (90\% of GDP) are not generally growth-enhancing (Arcand, Berkes, \& Panizza, 2012; Cecchetti \& Kharroubi, 2012; Law \& Singh, 2014). The liaison between financial development and economic expansion relies upon whether loans finance investment in productive assets or instead, nourish speculative bubbles.

Theoretically, any increase in transactions that comprise GDP must reflect commercial bank credit/money creation. This facilitates transactions of ultimate merchandise and services. Bank lending to the real economy should sustain roughly a one-to-one proportionality to the real economy. Commercial bank financing with the financial sector as a percentage of GDP has quadrupled since the 1950s, while the proportion of commercial bank lending to the real sector is still virtually the same (Harding, 2013).

Money is neutral if, when changing the money/credit supply, there is no real economic effect. An alteration in the supply of money accompanied by a proportionate change in the price level should then have no real effect on the economy. Extreme growth of the financial sector is inclined to transfer societal resources from productive to unproductive activities, and this structurally undermines the prospects for genuine socio-economic growth. Money/credit is not neutral, and not only does the amount of money/credit in the economy seem to be decisive, but also in which sector it is directed and how it is intermediated.

\section{Neoliberal Assumptions in the DSGE Models Has the Blind Leading the Blind}

Both the Neoclassical and New Keynesian theoretical completion of markets (Note 9) precluded models that inculcate money, credit and a banking financial sector even though DSGE models consume a significant portion of academic publications in macroeconomics' (An \& Schorfheide, 2007). These are extensively used in policy 
analyses by the ECB (Smets \& Wouters, 2003), the IMF (Botman, Karam, Laxton, \& Rose, 2007), and the Federal Reserve. Theoretically, a more intensive financial system should trim down transaction costs, increase investment unswervingly, and distribute capital and risk throughout the economy more efficiently (Pagano, 1993; Holmstrom \& Tirole, 1997). The nonexistence of money, debt, credit and banks (Note 10) from the conventional economic paradigm will simply not permit fundamental inquiries into systemic monetary insolvency and illiquidity to be addressed, let alone resolved (Mora, 2008). Worse still, introducing any genuine role for money into DSGE models undermines key model properties (Hahn, 1965; Godley \& Shaikh, 2002).

While DSGE models can incorporate frictional unemployment, sticky prices and wages (Chari, 2010), they neither helped predict the financial instability of 2007 nor subsequently granted insights and policy suggestions (Smets \& Wouters, 2003). Furthermore, the assumptions that structure DSGE models avert any meaningful modeling of finance (De Grauwe, 2010). This preemptive exclusion of modeling financial markets, despite being the workhorse macroeconomic model since the downfall of Keynesianism in the late 70s (An \& Schorfheide, 2007), has contributed to the on-going mis-assessment of credit/money since any inculcated financial variables would move incompatibly with the determinate equilibrium resolution of DSGE models.

Generally, the modeling of mainstream economics does not consider it relevant if and when, bank assets have systemically lost value, enabling central banks in a crisis to inadvertently subsidize insolvent commercial banks, who inflated assets partly due to not having sufficiently differentiated real sector assets from financial sector assets. Professor Robert Solow, a founder of modern macroeconomic theory, described this disconnect between DSGE models and the real world to Congress in July 2010, by stating that DSGE models: take it for granted that the whole economy can be thought about as if it were a single, consistent person or dynasty carrying out a rationally designed, long-term plan, occasionally disturbed by unexpected shocks, but adapting to them in a rational, consistent way. The protagonists of this idea make a claim to respectability by asserting that it is founded on what we know about microeconomic behavior, but I think that this claim is generally phony (Solow, 2010).

In a world of radical uncertainty, the financial engineering of central banks is dystopian. Mainstream economic theory has left central bankers misdirected when needing to shift from inflation-targeting in a financial universe of orderly markets to one of pervasive funding-illiquidity and market-illiquidity. Consequently, the financial engineering of central banks desperately needs financial-stability-targeting. Most disturbingly, conventional economic theory continues to not consider money, debt, or time as influential variables, leaving no accuracy toward the target.

The insights above, and not necessarily more math, would improve institutional vision. Blindness to the essence of money has enabled modeling in academic economics to become synonymous with mathematical deductive reasoning, which is restricted in its applicability to closed systems wherein an intrinsically constant mechanism, if triggered, acts in relative isolation. Such intrinsic and extrinsic closure conditions rarely occur in the social realm. This extreme rarity reflects the mistaken presupposition that what gets modeled somehow adequately captures the nature of the monetary realm, specifically banking, debt, credit and its milieu: time itself. In fact, such ideological negation of money within the paradigm culminates in a purview mathematically precise in its perilous irrelevancy when it comes to monetary disorder.

\section{The Neoclassical Model Wrongly Assumes Bank Leverage through Derivatives Only Helps Clear Markets into Equilibrium}

Much of the impetus for the creation of a wide range of derivative financial instruments, including options, was the belief that the auction economy could be mimicked by adding more markets, so society would gain by the effective "completion" of markets. In this pursuit, the financial sector recruited extremely clever individuals (mathematicians, physicists and engineers) whose job was to invent and price complicated, yet innovative credit instruments. However, insufficient resources were devoted to assessing the riskiness of the balance sheet as a whole. With a growing proportion of bank activity derived from trading complex instruments, it was difficult to accurately size how significant the risks were. Certainly, no investor could calculate such from the information made available by banks in their accounts or any other published source. Nor did the banks themselves seem to understand the risks they were taking. So much the worse for regulators relying on information provided by the banks, to surmise the actual potential risk. Mesmerized by sophisticated calculations, no one seemed to fully appreciate the non-observable risk emanating from a radical uncertainty embedded in empirical reality.

Derivatives, as synthetic instruments, do not represent economic activity. The size of exposure or potential losses inherent in derivatives can be many multiples of the value of the underlying equity or debt claims. The scope for introducing risk into the system rather than sharing it is obvious (Calomiris \& Haber, 2014). Yet, despite the 
absence of leverage, financial innovation in the presence of unspotted tail risk, can augment a latent systemic financial fragility (Gennaioli, Shleifer, \& Vishny, 2012).

In the period of easy credit (1980-2007) and deregulation, commercial banks were internally motivated to shift from real-economy ventures to gravitate toward borrowing heavily against rising asset prices, thus reaping a capital gain instead of higher-taxed, income. This combination of deregulation and the invention of derivatives had two effects. First, it separated the scale of the banks' balance sheets from the scale of real household and business activities in the economy. Under the neoclassical model, this cannot happen because lending to companies is limited by the amount they wish to borrow. However, there is no corresponding boundary on the extent of transactions in derivative financial instruments, and most buying and selling of derivatives is carried out by large banks and hedge funds, not enterprises. Eventually the size of the financial sector's balance sheet became monstrously unconnected from the activities of households and companies. Despite derivatives' gross market value plummeting to more than $\$ 20$ trillion by the end of 2014, it still amounts to one-half of the assets of the largest 20 banks in the world and is equal to total lending to households (consumers) and businesses (producers/labor/entrepreneurs) (Avdjiev, McGuire, \& Wooldridge, 2015).

Bank lending to the financial sector, rather than to the real economy, grew from $50 \%$ in the 1950 s, to $60 \%$ in the 1960s, to more than 80\% by 2007 (Bezemer, 2009). As a proportion of GDP, the amount of US finance embedded in the real sector has remained nearly invariable since the 1980s. In contrast, bank loans to other banks increased from $250 \%$ of GDP in 1980 to $580 \%$ of GDP in 2007 . This loan expansion went entirely towards the financial sector and explains why the financial sector was over 300\% greater in 2007 than in 1980 (Bezemer, 2009).

With this disparity came a change in commercial banks' focus from making loans, which requires a careful local assessment of potential borrowers, to trading securities, which involves a centralized operation to make and monitor transactions. This became possible with the rise of US investment banks when the Clinton administration repealed the Glass-Steagall Act in 1999. With the separation between depositor banks and investment banks erased, local "deposit" banks soon began taking the kinds of highly-leveraged risks associated with global investment banks. These small changes in localized domains led to unexpectedly large global effects rather than being averaged, out as savvy insurance companies acquired small banks so they too could pursue risky investments like bigger banks and investment banks. Even standalone investment banks previously organized as partnerships turned themselves into limited liability companies (Morgan Stanley in 1975, Lehman Brothers in 1982 and Goldman Sachs in 1999).

Size became an objective since a bank too important and too big to fail was able to borrow more cheaply; even a small advantage in funding costs meant that it could offer cheaper loans to its customers. That enabled such a bank to not only expand more rapidly than its rivals but also "merge" with smaller, less competitive banks. Thus, the size of the financial sector further expanded with a massive expansion of trading in derivatives, such as sub-prime mortgage lending. What is deemed mostly non-existent in macroeconomic models is Too Big Too Fail as well as crowding out bank credit for the real sector.

During the 2000s, foreigners poured massive amounts of capital into safe US assets, creating a shortage of safe fixed-income securities (Gennaioli et al., 2012). Financial markets met this demand by pooling and tranching mortgages and other loans. As with all securitization, these financially engineered AAA-rated mortgage backed securities (MBS) acted as a stand-in for government bonds and lowered bond rates, which rippled lower interest rates throughout the financial system (Ross, 1976; Allen \& Gale, 1994).

This resulted in mortgages and other asset backed securities worth trillions, that then poured into the gambit of unregulated shadow banking (Note 11). Investor perception of historically low default rates on US mortgages justified the low but safe interest rates of these "innovative" securities whose lack of regulation further enhanced the perception of bond-equivalence by hiding in legalese, complexity, and the hard science shine of the mathematical, risks which were not accounted for in the initial price (Gennaioli et al., 2012). Innovative securitzation in the realm of unregulated, and thus "shadow" banking, lowers interest rates, which constrained commercial banking from lending to the real sector, in particular SMEs, since the pervasive near-bond-equivalence interest rates create an insufficient return to justify entrepreneurial or manufacturing lending.

Enterprises not considered sufficiently creditworthy by the formal banking system raise money from outside the banking system by selling claims on their assets, including future income, directly to buyers. Although they interact, both the monetary and real economy's capital flows are distinct since the real sector's credit/money/deposits and other capital are distinct from the financial sector's assets/securities. Contained by the financial sector, the purpose of commercial banks (money/credit loan creators) and nonbanks (security trading 
and legally unable to create money/credit) is separated, even if commercial banks may jumble newly created money/credit with already existing-moneyed assets (Bezemer, 2011).

Regulators facilitated the methodical channeling of profits and savings from the real to the financial sector by allowing commercial banks to remove assets from their balance sheets and into a compilation of investments that make a profit on the disparity in price-spreads between structured pecuniary products (CDOs, MBS's etc.) and short-term debt (Note 12). By re-channeling credit/money through this unregulated "shadow banking" towards financial, instead of real, investments and capital formation, the vitality of capitalism is undermined (Wray, 2009).

Credit/money is not a veil in this case, but a significant macroeconomic driver still not recognized as existent by the DSGE models of the national economy. Credit is rationed (Stiglitz \& Weiss, 1981). Access to credit-money is determined by assessing creditworthiness, by what is considered an appropriate rate of interest, and by as much exploitation as the level of competition in the credit market allows. "Securitized" derivatives were deemed AAA in terms of default risk; whereas, a loan to an entrepreneur is seldom backed by collateral. Loans by the banking system are priced in accordance with a profit-maximizing strategy that includes a computational assessment of default risk. Securitized derivatives were viewed as almost bond-equivalent (AAA), which is why in the short-to-intermediate term, shadow banking reduces interest rates, despite financial innovation being more speculative than often advertised. Furthermore, this indigenous credit network by non-banks (shadow banking) struggles against commercial banks' efforts to control the terms on which credit is created. The banks' privileged access to central bank and governmental purview as well as regulatory jurisdiction renders the advantage. As this credit is created (via securitization) outside the formally regulated system which has direct access to central bank money, it diminishes systemic resiliency since in a crisis, these non-banks do not have access to the central bank's reserves and resources.

Thus far, orthodox measures to increase the money supply have been ineffective since commercial banks cannot be forced to lend to the real sector. With near-zero interest rates and an unsustainable ratio of government debt to GDP, it seems the limit of conventional monetary policy has been reached. The government and the central bank could channel credit towards investment in production and current consumption, with mild inflation the result.

The government's and central bank's ability to stimulate nominal demand is limited by the relationship between the government and central bank, which the government itself defines (Turner, 2002), and of equal importance: the norms governing orthodox fiscal practice.

\section{The Neoclassical Model Wrongly Assumes Finance Merely Lubricates the Real Sector, and So Money Cannot Create a Credit Crisis}

The empirical reality of financial bubbles and bursts contradicts neoliberal economic theory which the expansion of the finance sector and its attendant capital is fundamentally confined by the necessities of the economy's real sector. And thus cannot and should not deviate much from the industrial/real sector. Tight synergy persists between the financial and real sectors, with money-capital shadowing industrial-capital in turn lubricating the real sector. Money circulates to facilitate exchange (barter), optimizing the efficiency of transactions. Money "naturally" materializes from barter relations as society finds certain commodities to be acceptable and begins using them as media of exchange instead of keeping or consuming them (Menger, 1892). Over time, commodities with the most money-like properties (intrinsic value, portability, divisibility, homogeneity) naturally become adopted as money. Hence gold and silver coins, which possess all these properties, became the dominant medium for money, according to the classical account (Ryan-Collins, Greenham, Werner, \& Jackson, 2012).

In this a-historical (Note 13) paradigm, financial cycles tightly track real cycles. Financial bubbles cannot materialize and expand independent of the real sector of the economy yet money, also serves as an ultimate repository of concentrated wealth. Since the commodity with the most money-like properties largely determines the nature of money, the "commodity (or metallist) theory of money" hones in on the very properties that facilitate exchange (Jevons, 1885), lubricating the economy.

Contrary to the neoclassical "circular flow" paradigm, in advanced financial markets, demand for credit/money is no longer restricted to industrial or manufacturing ventures. A disproportionate amount of credit/money is sought for speculative debt financing in sophisticated markets (Note 14). Credit flows beyond those coupled to existing output must be coupled with some other asset market (superfluous in DSGE models). In a credit boom, the asset is successively sold at a profit, but each subsequent purchase bears proportionally more debt, tenuously balanced by the asset's increasing value. While individually profitable, asset trading is the game of musical chairs, the melody kept going only if the real sector provides sufficient credit/money to shoulder the growing debt 
encumbrance. At a certain point, the allure of capital gains mis-directs financial resources from real-sector investment, and escalates household debt-service. It then disables demand for real-sector production. Either way, disproportionate escalation of financial asset markets eventually becomes a monetary disorder.

The debt overhang created by credit/money funneled into asset markets simultaneously reduces the real economy's facility to pay-down that very debt. The financial sector is choking off the real sector, which is a neoclassical impossibility. Recall that DSGE models problematically assume money's function is to enable merchandise and services to flow within the real sector, thereby inextricably linking finance (beneficial to completing markets) to the real economy. By definition, this thwarts any germane analysis of credit cycles or monetary disorder. Yet, this is imperative both Keynes and Schumpeter insisted that the financial sector must be perceived as the dynamic independent force whereby capitalist economic relations are ordered and projected through the radical uncertainty of time. In a general sense, all capitalist activity is "speculative" in so far as there is no certainty, for example, that all goods will find buyers. However, Keynes cautioned against purely financial speculation (trading of claims to future income whether through stocks or other already-existing assets) in financial markets, since:

Speculators may do no harm as bubbles on a steady stream of enterprise. But the position is serious when enterprise becomes the bubble on a whirlpool of speculation. When the capital development of a country becomes a by-product of the activities of a casino, the job is likely to be ill-done (Keynes, 1936).

\section{Finance Matters, and Has Disengaged from the Real Sector of the Economy to a Perilous Extent}

The disconnect between financial depth (Note 15) and economic growth is highly problematic to mainstream economic theory. By focusing on the long-run neutrality of money, economic theory is disabled from making any theoretical advances, leaving modern monetary policy increasingly divorced from the reality of the real sector.

The basis in recent history for this shift from real sector growth to financial sector growth initially lies in the disintegration of the Bretton Woods international monetary system and its capital controls on international capital movements. Nixon's action in abandoning the dollar-gold standard in 1971 wrought further, almost inevitable, rapid transformations to all sectors of the money market. Deregulation of the restrictive practices in the closed, locally embedded stock markets, which the Bretton Woods restrictions had sustained, soon ignited a global market in equities/securities. Throughout the $80 \mathrm{~s}$, foreign investment flowed into Wall Street as competitive deregulation swept around the world, and by the mid-1990s, US firms dominated the global money and capital markets.

The US Federal Reserve's flow of funds data confirms that from the 1950s to the 1980s, non-financial firms' share increased from 25 -to-50\% of GDP. However, firms in the financial sector grew from an insignificant $2 \%$ to more than 50\% of GDP (Guttman, 1994; Greenspan, 1999). During the ascendancy of industrial-capital and labor between 1950 and 1970, the rentier portion of US corporate surplus increased gradually, from 20-to-30\% while from the late 1980s onwards it rose to between 60-and-70\% (Henwood, 1997). This reallocation is also apparent in the mounting ascendancy of finance within corporate governance throughout the conversion from post-war mass-production emphasizing growth and sales, to the present fixation with profitability and "shareholder value" (Ingham, 1999; Fligstein \& Calder, 2001). The change in corporate strategy from growth and output to a preoccupation with rates of returns to investment, grounded the downsizing and de-layering of manufacturing that occurred in the 1980s and early 1990s.

Since the 1980s, the financial sector expanded $600 \%$ faster than nominal GDP, resulting in a prowess switch from labor and manufacturing to one in which, "instead of being a servant, finance had become the economy's master" (Wolf, 2009). Most of this financial deepening (Note 16) in wealthy nations has come through additional household lending, as opposed to enterprise credit. Data from 45 countries (1994-2005) indicates enterprise credit is positively correlated with real economic expansion but no such link exists between economic growth and household credit (Beck, Büyükkarabacak, Rioja, \& Valev, 2012). In advanced economies, which have intense financial development, more financing is correlated with diminishing economic growth (Arcand et al., 2012). In fact, over the period 1965-2004, the credit/money pouring into the private sector had no statistically significant effect on the growth of GDP (Rousseau \& Wachtel, 2011). Thus, it seems the economic growth emerged from enterprise rather than household credit. Lending to the real sector is self-amortizing (Note 17).The debt created subsequently adds sufficient value in the ordinary course of business to repay both the principal and interest. This financing both expands the real economy relative to the debts created and is monetarily sustainable. In contrast, loans to purchase already-existing assets and financial instruments are not inherently self-amortizing. This may explain the paltry economic growth across high-income countries that tend to have a deep and extensive financial sector. 
Not surprisingly, finance and economic growth are synergistically beneficial only within a certain range (Shen \& Lee, 2006; Deidda \& Fattouh, 2002; Huang \& Lin, 2009), with a diminishing positive effect between more finance and economic growth as countries grow in wealth (Aghion, Burgess, Redding, \& Zilibotti, 2005). At a certain point, even private sector credit begins injecting harmful marginal effects on economic growth, commensurate with increased systemic macroeconomic volatility (Easterly, Islam, \& Stiglitz, 2000). Finance begins to suppress production expansion when credit to the private sector surmounts $90-100 \%$ of GDP. At the time of the financial crisis, US private credit had risen to more than 200\% of GDP. Apparently, had this ratio been closer to $100 \%$ of GDP, productivity growth would have increased to more than 150 basis points (Cecchetti \& Kharroubi, 2012).

At that point, a U-shaped and non-monotone connection exists between the volatility of economic growth and financial depth, suggesting that GDP instability begins to escalate when private-sector credit attains $100 \%$ of GDP (Easterly et al., 2000). When private credit exceeds GDP, a drag on productivity growth ensues. Theoretically, this is not supposed to happen if money is neutral, merely a veil covering the real economy that must be lifted (assumed away) to see the real economy. Something is dangerously amiss.

\section{The Long Winding Road}

Once upon a time, it was accepted that money was the 'neutral veil' behind which lay a fundamental substratum of human material existence (Note 18) which consists in the propensities of the factors of production and the utility of commodities. At most, money exists as an arbitrarily chosen commodity that is given a numerical value (numeraire) that enables the formal macroeconomic models to operate. Generations of orthodox economists have insisted that money does not comprise any of the essentials of economic life, and that it does not matter.

Money is not neutral. Money/credit creation has a pre-allocative and pre-distributive function. Money and capital markets are not self-regulating and stabilizing at a point of equilibrium of supply and demand. Banks create credit/money, and contrary to the circular-flow model do not merely transfer it from savers to investors. By leveraging debt disproportionate to the real economy, money, banking, and finance can create systemic instability. The elastic creation of credit/money through proper acts of lending is how the dynamic elements within the capitalist economy can be actualized.

Real rates of interest should neither be high enough to elicit a shift of capital from production, jeopardizing income generation for servicing and repaying of debt, nor fall to a point that demotivates creditors. Entrepreneurial (and consumer) debtors tussle with creditor capitalists over the real rate of interest (Smithin, 2003). Any outcome will be the result of many factors in which chance and contingency, as ever, will play an important part. However, any successful expansion of infrastructural power, using credit-money, can only occur within a legitimate institutional structure founded upon a tolerable and feasible arrangement between debtors and creditors.

When dominance by either constituency becomes extreme (hyperinflation or debt deflation) the tussle may give way to a rebalancing of power relations and a new settlement. Thus, money cannot be neutral. Rather, it is the most powerful of the social technologies, produced and controlled by specific monetary interests and is also inherently unstable. Consequently, the pronouncements of central bankers and their expert committees have become the most important signals upon which the money markets judge the creditworthiness of the most important debt (Governmental). These judgments establish a rate of interest on long-term government debt that is the benchmark for all the other rates upon which the rest of the capitalist system depends. Stable money expresses a stable, but not necessarily equal, balance of power (Pixley, 2009). Moreover, the game is forever ongoing, for fresh framings are at all times possible, continually linking a bricolage of novel agencements (Note 19), innovative notions of performativity, able to make statements institutionally visible, enliven a system of beliefs that infiltrate agents' minds, with a bit of luck to the Greater Good.

Money is used by the diverse interests in the continuing economic struggle. It is also a societal resource, an infrastructural power. Too huge of a concentration of power in any one class (labor, producers, rentiers/creditors, etc.) would inhibit the dynamism of the struggle. The notion of money as a neutral medium in an economy of barter-exchange, enfeebles labor and producers with a diminished ability to reach a proper socio-economic dynamism since there can be no meeting of interests without truth.

The perception of neutral money as a representative exchange medium for the market is a phantasm that hypnotizes institutions from perceiving money as an "agencement" within the societal complex of credit/money and debt. Money is constituted by the reliability of the payments system, which, if upset by large-scale defaults, could initiate a systemic financial avalanche (Otero-Iglesias, 2015). Production of the credit/money supply is constantly subject to painstaking control, and is not allowed to respond without restraint to demand. The 
scarceness of money is always the product of meticulously constructed societal and political arrangements; an evident contradiction in the persistence that something without effectiveness (the 'neutral veil') should be strictly controlled. Institutional arrangement and regulations must exist to preserve the money supply in proportion to real economic growth. Therefore, controlling such events by acting as lender of last resort is, perhaps, the most imperative and obligatory function of a central bank, over and above price stability (Mayer, 2001).

Any empiricist or bank clerk would presume that time, banking, money, credit and debt flows, as well as the diverse effect each may have, reside at the core of current macroeconomic models. These models presently exclude any differentiation between credit flows beneficial to GDP and those destabilizing to the economy (non-GDP) while simultaneously ignoring the role of debt altogether (Godley \& Lavoie, 2012). In 1983, Bernanke indicated, "only the older writers seemed to take the disruptive impact of financial breakdown for granted" (Bernanke, 1983). These Ancients must be remembered to prevent the circular flow of history from repeating itself.

The current macroeconomic models necessitate a restating of the function of credit, as well as its balance sheet counterpart, debt within the economic system. As yet, any prominence of debt or credit is profoundly at odds with the methodology constituting such macroeconomic models, as Eggertsson and Nobel laureate Paul Krugman (2012) acknowledged:...despite the prominence of debt in popular discussion ... and the long tradition of invoking debt as a key factor in major economic contractions, there is a surprising lack of models that correspond at all closely to the concerns about debt ... Even now, much analysis (including my own) is done in terms of representative-agent models, which by definition can't deal with the consequences of the fact that some people are debtors while others are creditors.

Moreover, while truly reintroducing credit/money/debt into macroeconomics turns out to be extremely challenging from a modeling perspective. Doing so is necessary, if the dismal science is going to have anything to say about the real world. Otherwise, the neoclassical systemic outlook on money, credit creation, and venture financing, notwithstanding its internal logic, mathematical rigor, and performative elegance, will be rendered obsolete, an irrelevant closed system boxed in coffin wood.

By not considering money as a vital part of an economy, general equilibrium theory is no longer useful to show if and how the economy as a whole converges towards equilibrium, and perhaps then discover the mechanism by which it does so. A better theoretical pursuit would be to ascertain if a financial bubble tracks real sector enlargement or if it is fashioned in the absence of such an expansion. If the economy is self-equilibrating then there is no need to account for the incremental snowballing of financial sector disproportion, and the resultant deformation in real expenditures and capacity buildup (Kohn, 2006). Disequilibria exists and seem inherent, and for over three decades in complex financial markets, finance capital has become increasingly and principally autonomous of industrial capital, critically undermining the neoclassical theory towards: 1) general equilibrium; 2) the circular flow model; and 3) the money supply being inherently secured from domestic savings.

Finance should foster the economy, and not vice versa. The primary concern at present should not be to revitalize asset markets, but to revamp a distended and dysfunctional financial sector towards one that aids the real economy with sustainable and cost-efficient comportment. The regulatory and policy milieu must institutionally discourage the tax-savvy quest for capital gains, and instead favor the expansion of the real economy; if necessary, with credit-redirection. Macro-economically allowing for unemployment in determining monetary policy, and not just inflation, is justified, already being a keystone within the US Federal Reserve's official mission, and a mandated intuitional concern.

Who should dictate the money supply (the central bank, the government, or the banking sector)? Not one of them. All of them. It is, hopefully, a societal orchestral in which no partner dominates to the ruination of the National Dance.

\section{Acknowledgements}

The author would like to thank Professor Valerie Sabatier, Program Director DBA, at the Grenoble Ecole de Management. The Author would also like to thank Professor Francois Desmoulins-Lebeault, Finance Professor at Grenoble Ecole de Management as well as Lois M. Shelton, Associate Editor, IJEBR; Program Director of the Grenoble DBA at CSUN; Management Professor, CSUN.

\section{References}

Adrian, T., Moench, E., \& Shin, H. S. (2013). Leverage asset pricing. FRB of New York Staff Report, (625). https://doi.org/10.2139/ssrn.2321180

Aghion, P., \&Durlauf, S. (Eds.). (2005). Handbook of economic growth (Vol. 1). Elsevier. 
Aghion, P., Burgess, R., Redding, S., \& Zilibotti, F. (2005). Entry liberalization and inequality in industrial performance. Journal of the European Economic Association, 3(2-3), 291-302. https://doi.org/10.1162/jeea.2005.3.2-3.291

Allen, F., \& Gale, D. (1994). Financial innovation and risk sharing. MIT press.

An, S., \&Schorfheide, F. (2007).Bayesian analysis of DSGE models. Econometric Reviews, 26(2-4), 113-172. http://dx.doi.org/10.1080/07474930701220071

Anonymous. (2011). Causes of financial instability: Don't forget finance. Levy Economics Institute of Bard College Working Paper, (665). http://dx.doi.org/10.2139/ssrn.1808020

Arcand, J. L., Berkes, E., \&Panizza, U. (2015). Too much finance? Journal of Economic Growth, 20, 105-148. http://dx.doi.org/10.1007/s10887-015-9115-2

Avdjiev, S., McGuire, P., \& Wooldridge, P. (2015). Enhancements to the BIS international banking statistics. IFC Bulletin, 39, 514-9.

Beck, T., Büyükkarabacak, B., Rioja, F. K., \& Valev, N. T. (2012). Who gets the credit? And does it matter? Household vs. firm lending across countries. The BE Journal of Macroeconomics, 12(1), 1-46. http://dx.doi.org/10.1515/1935-1690.2262

Bernanke, B. S. (1983). Non-monetary effects of the financial crisis in the propagation of the Great Depression. http://dx.doi.org/10.3386/w1054

Bezemer, D. (2009). Lending must support the real economy. Financial Times, 5(11), 2009.

Board, F. S. (2013). Global shadow banking monitoring report 2012. Basel: Bank for International Settlement.

Botman, D. P., Karam, P. D., Laxton, D., \& Rose, D. (2007). DSGE Modeling at the Fund: Applications and Further Developments. IMF working papers, 1-41. https://doi.org/10.5089/9781451867640.001

Cahuc, P., \& Challe, E. (2012). Produce or speculate? Asset bubbles, occupational choice, and efficiency. International Economic Review, 53(4), 1105-1131. http://dx.doi.org/10.1111/j.1468-2354.2012.00713.x

Calomiris, C. W., \& Haber, S. H. (2014). Fragile by design: The political origins of banking crises and scarce credit. Princeton University Press.

Caporale, G. M., \& Howells, P. (2001). Money, credit and spending: Drawing causal inferences. Scottish Journal of Political Economy, 48(5), 547-557. http://dx.doi.org/10.1111/1467-9485.00214

Cecchetti, S. G., \& Kharroubi, E. (2012). Reassessing the impact of finance on growth.

Chari, V. V. (2010). Testimony before the committee on Science and Technology, Subcommittee on Investigations and Oversight. US House of Representatives. July, 20, 2010.

De Grauwe, P. (2010). The scientific foundation of dynamic stochastic general equilibrium (DSGE) models. Public Choice, 144(3-4), 413-443. https://doi.org/10.1007/s11127-010-9674-x

Deidda, L., \& Fattouh, B. (2002). Non-linearity between finance and growth. Economics Letters, 74(3), 339-345. http://dx.doi.org/10.1016/S0165-1765(01)00571-7

Disyatat, P. (2011). The bank lending channel revisited. Journal of money, Credit and Banking, 43(4), 711-734. http://dx.doi.org/10.1111/j.1538-4616.2011.00394.x

Durlauf, S. N., \& Blume, L. E. (2008). The New Palgrave: Dictionary of Economics, Lardner-network goods (theory). In The New Palgrave: Dictionary of Economics (Vol. 5, pp. 3595-4511). Palgrave Macmillan UK.

Easterly, W., Islam, R., \& Stiglitz, J. E. (2000). Shaken and Stirred: Explaining Growth Volatility. The World Bank, Washington, DC., mimeo.

Eggertsson, G. B., \& Krugman, P. (2012). Debt, deleveraging, and the liquidity trap: A Fisher-Minsky-Koo approach. The Quarterly Journal of Economics, 127(3), 1469-1513. http://dx.doi.org/10.1093/qje/qjs023

Fisher, R. W. (2013). Horseshift!(With reference to Gordian Knots). Speech given at the National Association of State Retirement Administrators 59th Annual Conference. Portland, Oregon. August 5, 2013.

Fligstein, N., \& Calder, R. (2001). Architecture of Markets. Emerging Trends in the Social and Behavioral Sciences: An Interdisciplinary, Searchable, and Linkable Resource.

Fostel, A., \& Geanakoplos, J. (2014). Leverage, Securitization and Shadow Banking: Theory and Policy.

Friedman, B. (2012). Monetary Policy, Fiscal Policy, and the Efficiency of Our Financial System: Lessons from 
the Financial Crisis. International Journal of Central Banking, 8(S1), 301-09.

Gennaioli, N., Shleifer, A., \& Vishny, R. (2012). Neglected risks, financial innovation, and financial fragility. Journal of Financial Economics, 104(3), 452-468. http://dx.doi.org/10.1016/j.jfineco.2011.05.005

Godley, W., \& Lavoie, M. (2006). Monetary economics: an integrated approach to credit, money, income, production and wealth. Berlin, DE: Springer.

Godley, W., \& Shaikh, A. (2002). An important inconsistency at the heart of the standard macroeconomic model. Journal of Post Keynesian Economics, 24(3), 423-441. http://dx.doi.org/10.1080/01603477.2002.11490334

Greenspan, A. (1999). Mr. Greenspan asks whether efficient financial markets mitigate financial crisis. In Remarks before the Financial Markets Conference of the Federal Reserve Bank of Atlanta, Sea Island Georgia, BIS Review (Vol. 114).

Guttman, R. (1994). How Credit-Money Shapes the World Economy. ME Sharpe.

Hahn, F. H. (1965). On some problems of proving the existence of an equilibrium in a monetary economy. The Theory of Interest Rates, 126-135.

Harding, R. (2013). Corporate investment: A mysterious divergence. Financial Times, 24.

Henwood, D. (1997). Wall Street: how it works and for whom (pp. 22-7). London: Verso.

Holmstrom, B., \& Tirole, J. (1997). Financial intermediation, loanable funds, and the real sector. The Quarterly Journal of economics, 663-691. http://dx.doi.org/10.1162/003355397555316

Huang, H. C., \& Lin, S. C. (2009). Non - linear finance-growth nexus. Economics of Transition, 17(3), 439-466. http://dx.doi.org/10.1111/j.1468-0351.2009.00360.x.

Humphrey, C. (1985). Barter and economic disintegration. Man, 48-72. http://dx.doi.org/10.2307/2802221

Ingham, G. (1999). Class inequality and the social production of money. The Sociological Review, 47(S2), 66-86. http://dx.doi.org/10.1111/j.1467-954X.1999.tb03495.x

Jevons, W. S. (1896/1875). Money and the Mechanism of Exchange. New York: Appleton and Company.

Keen, S. (2013). A monetary Minsky model of the Great Moderation and the Great Recession. Journal of Economic Behavior \& Organization, 86, 221-235. http://dx.doi.org/10.1016/j.jebo.2011.01.010

Keynes, J. M. (1936). The general theory of interest, employment and money.

King, M. (2010). Banking: from Bagehot to Basel, and back again. The Second Bagehot Lecture, Buttonwood Gathering, 25.

Kohn, D. (2006, March). Monetary policy: A journey from theory to practice. In a European Central Bank Colloquium held in honor of Otmar Issing. Frankfurt, Germany.

Kydland, F. E., \& Prescott, E. C. (1990). Business cycles: Real facts and a monetary myth. Real Business Cycles: A Reader, 383.

Law, S. H., \& Singh, N. (2014). Does too much finance harm economic growth? Journal of Banking \& Finance, 41, 36-44. http://dx.doi.org/10.1016/j.jbankfin.2013.12.020.

Mayer, M. (2001). The Fed: The Inside Story of how the World's Most Powerful Financial Institution Drives the Market. Simon and Schuster.

Menger, C. (1892). On the Origins of Money. Economic Journal, 2, 239-255. http://dx.doi.org/10.2307/2956146

Mora, C. E. T. (2008). DSGE Models and Central Banks (No. 258). Bank for International Settlements, Monetary and Economic Department. http://dx.doi.org/10.5018/economics-ejournal.ja.2009-16

Otero-Iglesias, M. (2015). Stateless euro: The euro crisis and the revenge of the chartalist theory of money. JCMS: Journal of Common Market Studies, 53(2), 349-364. http://dx.doi.org/10.1111/jcms.12223

Pagano, M. (1993). Financial markets and growth: An overview. European Economic Review, 37(2-3), 613-622. http://dx.doi.org/10.1016/0014-2921(93)90051-B

Philippon, T. (2010). Financiers versus engineers: Should the financial sector be taxed or subsidized? American Economic Journal: Macroeconomics, 2(3), 158-182. http://dx.doi.org/10.1093/qje/qjs030.

Philippon, T., \& Reshef, A. (2009). Wages and human capital in the US financial industry: 1909-2006 (No. w14644). National Bureau of Economic Research. 
Phillips, J. (2006). Agencement/assemblage. Theory, Culture \& Society, 23(2-3), 108-109.

Pigou, A. C. (1949). The Veil of Money. London: Macmillan.

Pixley, J. (2009). 'The Current Crisis of Capitalism': What Sort of Crisis?. The Economic and Labour Relations Review, 19(2), 59-67.

Rajan, R. G., \& Zingales, L. (1996). Financial dependence and growth (No. w5758). National bureau of economic research. http://dx.doi.org/10.3386/w5758

Ross, S. A. (1976). Options and efficiency. The Quarterly Journal of Economics, 75-89. http://dx.doi.org/10.2307/1886087

Rousseau, P. L., \& Wachtel, P. (2011). What is happening to the impact of financial deepening on economic growth?. Economic inquiry, 49(1), 276-288. http://dx.doi.org/10.1111/j.1465-7295.2009.00197.x

Ryan-Collins, J., Greenham, T., Werner, R., \& Jackson, A. (2011). Where does money come from? A guide to the UK monetary and banking system. New Economics Foundation.

Shen, C. H., \& Lee, C. C. (2006). Same financial development yet different economic growth: Why? Journal of Money, Credit and Banking, 1907-1944.

Smets, F., \& Wouters, R. (2003). An estimated dynamic stochastic general equilibrium model of the euro area. Journal of the European economic association, 1(5), 1123-1175. http://dx.doi.org/10.1162/154247603770383415

Smithin, J. N. (2003). Controversies in monetary economics. Edward Elgar Publishing.

Solow, R. (2010). Building a science of economics for the real world. House Committee on Science and Technology Subcommittee on Investigations and Oversight, 20.

Stiglitz, J. E., \& Weiss, A. (1981). Credit rationing in markets with imperfect information. The American Economic Review, 71(3), 393-410.

Tobin, J. (1984). On the efficiency of the financial-system. Lloyds Bank Annual Review, (153), 1-15.

Turner, A. (2002). Europe's best defence against deflation. Financial Times, 4.

Werner, R. A. (2014). Can banks individually create money out of nothing?-The theories and the empirical evidence. International Review of Financial Analysis, 36, 1-19. http://dx.doi.org/10.1016/j.irfa.2014.07.015.

Werner, R. A. (2015). A lost century in economics: Three theories of banking and the conclusive evidence. International Review of Financial Analysis.

Werner, R. A. (2016). A lost century in economics: three theories of banking and the conclusive evidence. International Review of Financial Analysis, 46, 361-379. http://dx.doi.org/10.1016/j.irfa.2015.08.014

Williamson, J. (Ed.). (1994). The political economy of policy reform. Peterson Institute.

Wolf, M. (2009). Why dealing with the huge debt overhang is so hard. Financial Times, 28.

Wray, L. R. (2009). The rise and fall of money manager capitalism: A Minskian approach. Cambridge Journal of Economics, 33(4), 807-828. http://dx.doi.org/10.1093/cje/bep024

\section{Notes}

Note 1.This is the famous Keynesian term "liquidity trap" or "liquidity preference".

Note 2. Banks also allegedly intermediate money athwart space (savings in New Orleans may finance loans in Atlanta); and time (current pooled savings are loaned as a 30-year mortgage). This 'maturity' transformation of short-term savings into long-term loans ensures savings circulate within the economy instead of lying dormant.

Note 3. This mythical money-credit-creation process also presumes the pretense that risk-free deposits can be supported by risky assets. Genuinely safe deposits cannot coexist with risky assets (King, 2010).

Note 4. Money is analytically voided in the most prestigious mathematically sophisticated macroeconomic models, such as Arrow-Debreu 's general equilibrium or the capital asset pricing model (CAPM) of Sharpe (1964).

Note 5. Presently, substantial amounts of the monetary base are heaped up as excess reserves of commercial banks unwilling or unable to secure worthy borrowers. Additionally, other types of surplus cash are lying unsown on the balance sheets of businesses or being utilized for stock buybacks to raise dividend payouts so as 
to enhance company stock prices (Fisher, 2013). Richard Fisher is president of the Federal Reserve Bank of Dallas.

Note 6. A pro-cyclical dynamic wherein ever-rising asset prices continually improve the net worth of borrowers in the short-term, permitting the accumulation of extra debt which fuels further asset price appreciation. (Adrian, Moench, \& Shin, 2013; Fostel \& Geanakoplos, 2014).

Note 7. These models allow for random probability distribution (hence stochastic), and analyzing transitions from one state of poise to another (hence dynamic).

Note 8. Financial development can cause economic growth in industrial sectors dependent on finance to meld with sophisticated technological infrastructure and core competencies, thereby affording a necessarily larger national financial sector (Rajan \& Zingales, 1996).

Note 9. Markets are assumed to clear under the conditions of 'perfect information': Where the quantity supplied meets the quantity demanded, consumers 'automatically' exchange goods and services, without delay or friction (Pigou, 1949). The Veil of Money. London: Macmillan. Supply is then determined by the production costs of the commodity and demand by consumers ' marginal utility' (how much they desire the commodity in question) (Durlauf \& Blume, 2008).

Note 10. In numerous nations that are banking centers, this theoretically nonexistent sector dwarfs the GDP of the country itself. Case in point, the proportion of the nonbank financial sector (a sub-component of the total finance sector) to GDP is 90\% in the Netherland s, 370\% in the United Kingdom, 260\% in Singapore, and 210\% in Switzerland (Board, 2013).

Note 11. In the US, "shadow banking" has resulted in total credit to the private sector being nearly four times greater than credit extended by deposit-taking banks (Arcand, Berkes, \& Panizza, 2012).

Note 12. Also called Special Investment Vehicles (SIVs).

Note 13. The historical evidence of' pure barter' economies is also lacking. Anthropologists assert that a 'pure bartering economy' as hypothesized by classical economists has never existed, and not only doubt the emergence of money from barter but also believe that barter itself has been misconstrued because of the persistence of the creation-myth in classical and neoclassical economics that in barter lie the origins of money and hence of modern capitalism.Humphrey, C. (1985). Barter and economic disintegration (Humphrey, 1985; Ryan-Collins, Greenham, Werner, \& Jackson, 2012).

Note 14. Stock markets, futures markets, real estate markets, derivatives markets consume vast amounts of money/credit in furtherance of asset appreciation, which are largely in the eventual form of capital gains. This form of taxation entices capital towards (non-GDP) asset appreciation.

Note 15. Private credit as a fraction of GDP.

Note 16. Financial depth is most often measured by the amount of credit as a percentage share of GDP.

Note 17. A loan in which the periodic payments consist of both principal and interest such that the loan will be paid off by the end of a scheduled term.

Note 18. This fundamental substratum of human material existence is also held to be universally applicable. Thus, time, history and culture are in the long run, analytically unimportant; and is just the milieu from which micro-economic analysis can extract the 'rational core' (Williamson, 1994).

Note 19. French word essentially meaning institutional layout, arrangement. For a more thorough connotation, see Phillips, 2006.

\section{Copyrights}

Copyright for this article is retained by the author(s), with first publication rights granted to the journal.

This is an open-access article distributed under the terms and conditions of the Creative Commons Attribution license (http://creativecommons.org/licenses/by/4.0/). 